\title{
Impacts of increasing fine fuel loads on acorn germination and early growth of oak seedlings
}

\author{
Rachel E. Nation ${ }^{1}$, Heather D. Alexander ${ }^{1,2^{*}}$ (D), Geoff Denny ${ }^{3}$, Jennifer K. McDaniel ${ }^{1,4}$ and Alison K. Paulson ${ }^{1}$
}

\begin{abstract}
Background: Prescribed fire is increasingly used to restore and maintain upland oak (Quercus L. spp.) ecosystems in the central and eastern US. However, little is known about how prescribed fire affects recently fallen acorns under different fine fuel loads, which can vary with stand composition and basal area, burn season, and fire frequency. We conducted plot-level $\left(1 \mathrm{~m}^{2}\right)$ burns in an upland oak stand in northern Mississippi, USA, during December 2018, using single (i.e., ambient), double, and triple fine fuel loads, representative of those in nearby unburned and recently fire-treated, closed-canopy stands. Pre burn, we placed 30 acorns each of white oak (Quercus alba L.) and Shumard oak (Quercus shumardii Buckley) $\sim 1 \mathrm{~cm}$ below the litter surface in five plots of each fuel treatment. Immediately post burn, we planted unburned and burned acorns in a greenhouse. After $50 \%$ of each species' unburned acorns germinated, we measured percent germination and height, basal diameter, and leaf number of germinating seedlings weekly for 11 weeks. Then, we harvested seedlings to determine above- and belowground biomass.

Results: The single fuel treatment reduced acorn germination rates of both species to $\sim 40 \%$ compared to $\sim 88 \%$ in unburned acorns. When burned in double and triple fuel loads, acorns of both species had a $<5 \%$ germination rate. There was no difference in basal diameter, leaf number, or biomass of seedlings from burned versus unburned acorns for either species. However, seedlings originating from burned acorns of both species were $~ 11 \%$ shorter than those from unburned acorns. Thus, both species responded similarly to fuel load treatments.

Conclusions: Acorns of both species exhibited greater survival with lower fine fuel loads, and consequently lower percent fuel consumption. Acorns germinating post fire generally produced seedlings with growth patterns similar to seedlings originating from unburned acorns. These findings indicate that regular, repeated prescribed fires or canopy reductions that limit fine fuel accumulation and create heterogeneous fuel beds are likely to increase acorn germination rates relative to unburned sites or those with recently introduced fire.
\end{abstract}

Keywords: burn, leaf litter, prescribed fire, Quercus alba, Quercus shumardii, Shumard oak, white oak

\footnotetext{
* Correspondence: heather.alexander@auburn.edu

'Department of Forestry, Forest and Wildlife Research Center, Mississippi

State University, 775 Stone Boulevard, Starkville, Mississippi 39762, USA

${ }^{2} S c h o o l$ of Forestry and Wildlife Sciences, Auburn University, 602 Duncan

Drive, Auburn, Alabama 36849-5418, USA

Full list of author information is available at the end of the article
}

\section{Springer Open}

(- The Author(s). 2021 Open Access This article is licensed under a Creative Commons Attribution 4.0 International License, which permits use, sharing, adaptation, distribution and reproduction in any medium or format, as long as you give appropriate credit to the original author(s) and the source, provide a link to the Creative Commons licence, and indicate if changes were made. The images or other third party material in this article are included in the article's Creative Commons licence, unless indicated otherwise in a credit line to the material. If material is not included in the article's Creative Commons licence and your intended use is not permitted by statutory regulation or exceeds the permitted use, you will need to obtain permission directly from the copyright holder. To view a copy of this licence, visit http://creativecommons.org/licenses/by/4.0/. 


\section{Resumen}

Antecedentes: Las quemas prescriptas se están usando de manera incremental para restaurar y mantener los ecosistemas de robles de altura (Quercus L. spp.) en el centro y este de los EEUU. Sin embargo, se conoce poco sobre como las quemas prescriptas afectan las bellotas recientemente caídas bajo diferentes cargas de combustibles finos, los que pueden variar con la composición de rodal y el área basal, la estación de quema y la frecuencia del fuego. Condujimos quemas a nivel de parcelas $\left(\mathrm{de} 1 \mathrm{~m}^{2}\right.$ ) en un rodal de roble de altura en el norte de Mississippi, EEUU, durante diciembre de 2018, usando distintas cargas de combustible fino: simple (i.e., control), doble y triple, todos representativos del combustible presente en áreas adyacentes no quemadas y recientemente tratadas con quemas prescriptas en rodales con doseles cerrados. Antes de las quemas, ubicamos 30 bellotas de cada una de las especies de roble blanco (Quercus alba L.) y roble shumard o roble manchado (Quercus shumardii Buckley) $\sim 1 \mathrm{~cm}$ debajo del mantillo en cinco parcelas de cada tratamiento de combustibles. Inmediatamente luego del tratamiento de fuego, sembramos bellotas quemadas y no quemadas en un invernáculo. Luego de que germinaran aproximadamente el 50\% de las bellotas no quemadas de cada especie, medimos el porcentaje de germinación, y la altura, diámetro basal, y el número de hojas de las plántulas germinadas, por 11 semanas. Luego, cosechamos las plántulas para determinar su biomasa aérea y radical.

Resultados: El tratamiento de combustible simple (o control) redujo la germinación de bellotas de ambas especies al $\sim 40 \%$ comparado con un $\sim 88 \%$ en bellotas no quemadas. Cuando éstas fueron quemadas en los tratamientos con doble o triple carga de combustible, la tasa de germinación de las bellotas de ambas especies fue $<5 \%$. No hubo diferencias en diámetro basal, número de hojas o biomasa de plántulas de bellotas quemadas y no quemadas para ambas especies. Sin embargo, las plántulas originadas de bellotas quemadas de ambas especies fueron un $\sim 11 \%$ más cortas que aquellas emergidas de bellotas no quemadas. Por lo tanto, ambas especies respondieron de manera similar a los tratamientos de distintas cargas de combustible.

Conclusiones: Las bellotas de ambas especies exhibieron una supervivencia mayor con menores cargas de combustible y consecuentemente tuvieron menores porcentajes de consumo de combustible. Las bellotas que germinan luego de una quema generalmente producen plántulas con patrones de crecimiento similares a aquellas originadas por bellotas no quemadas. Estos resultados indican que quemas prescriptas regulares y repetidas, o bajo reducción de doseles que limiten la acumulación de combustibles finos y creen camas de combustibles heterogéneas, probablemente incrementen la tasa de germinación de bellotas en relación a los sitios no quemados o aquellos en los que el fuego se ha introducido recientemente.

\section{Background}

Historically pyrophytic and open-canopied upland oak savannas and woodlands of the central and eastern US are shifting to closed-canopy forests occupied by shadetolerant (i.e., mesophytic) or opportunistic species that are often fire sensitive (Hanberry et al. 2012; Hanberry et al. 2020). Large overstory oaks (Quercus L. spp.) still dominate forest stands (Fei et al. 2011), and oak seedlings continue to establish in the understory. However, sapling and midstory oaks are largely absent (e.g., Dyer and Hutchinson 2019; Izbicki et al. 2020), leading to a regeneration "bottleneck." Instead, mesophytic or generalist species, like red maple (Acer rubrum L.), sugar maple (A. saccharum Marshall), and American beech (Fagus grandifolia Ehrh.), proliferate (Fei and Steiner 2007; Knott et al. 2019) and are poised to replace oaks following overstory mortality. Oaks play an important foundational role in these ecosystems, especially as a food resource for many animals (McShea et al. 2007) and in regulating water (Alexander and Arthur 2010; Siegert et al. 2019) and nutrient cycling (Washburn and
Arthur 2003; Alexander and Arthur 2014). Thus, there has been great interest in understanding causes of these shifts and then determining potential remedies, including the restoration of fire and canopy-opening disturbances (Arthur et al. 2012; Brose et al. 2014; Dey 2014).

This shift has been partly attributed to intentional fire exclusion starting in the early 1930s (Abrams 1992; Abrams and Nowacki 2008). Frequent and widespread fires were common across the region during or just prior to the establishment of current oak overstories (McEwan et al. 2007; Hutchinson et al. 2008). But soon after the enactment of fire exclusion policies, oak establishment declined and establishment of species like red maple increased (Hutchinson et al. 2008). Further, upland oaks have fire-adapted traits including large root systems that facilitate resprouting after top-kill and thick bark to protect from fire damage (Abrams 1992). Thus, there is a clear connection between oak dominance and fire disturbance, although fire exclusion likely interacted with other factors like climate change, land-use change, and altered herbivore pressure to facilitate compositional and 
structural shifts away from oak dominance (McEwan et al. 2011).

In an attempt to restore or maintain oak dominance, recent studies have experimentally investigated the efficacy of prescribed fire, alone or in combination with canopy reductions (e.g., thinning and herbicide application), to suppress mesophytic and generalist species, by increasing light and reducing competition with advanced oak regeneration (Arthur et al. 2012; Brose et al. 2013; Brose et al. 2014; Brose 2014). The utility of prescribed fire alone for this purpose, especially when applied only once, has been mixed, likely because (1) competing nonoak species have grown large enough during the era of fire exclusion to resist fire (Bova and Dickinson 2005; Hammond et al. 2015), (2) fires often fail to increase light levels through removal of midstory non-oak competitors or canopy gap creation (Chiang et al. 2005; Alexander et al. 2008), and (3) oaks of seedling and sapling size are often resprouts with insufficient carbohydrate reserves to respond to increased light when and if available post fire (Dillaway et al. 2007). Thus, not surprisingly, an increasing number of studies indicate that improving the competitive status of advanced oak regeneration requires the repeated application of prescribed fires, often in combination with canopy reductions (Brose et al. 2013; Brose 2014).

Although prescribed fire and canopy reductions are often targeted at improving conditions for advanced oak regeneration, both management tools have implications for recently fallen acorns, a key life history stage in the oak regeneration process (Arthur et al. 2012). Prescribed fires in the central and eastern US are often conducted from November to April, when plants are largely dormant and fuels are receptive to burning (Knapp et al. 2009), but this is also the period following seedfall. Although some acorns are cached by animals and protected from fire, many acorns remain on or near the leaf litter surface (Cain and Shelton 1998; Greenberg et al. 2012; Greenler et al. 2020). Because most fires are lowintensity surface fires that consume mostly dead fine fuels (i.e., leaf litter; Arthur et al. 2017), acorns in the litter layer may be vulnerable to fire (Auchmoody and Smith 1993; Cain and Shelton 1998; Greenberg et al. 2012). Some management recommendations include avoiding prescribed fires following good acorn crops (Auchmoody and Clay Smith 1993; Brose 2004) because viable acorns in mast years are especially important for satiating seed predators to allow germination of acorns and seedling establishment (Greenberg and Zarnoch 2018). Because oaks do not have a seedbank and depend on masting events for regenerative success, acorn susceptibility to fire could be especially important when prescribed fire is conducted soon after these pulsed seeding events. However, vulnerability is likely to vary with fine fuel loads, which change both spatially and temporally depending on burn season, time since last fire, and canopy openness (Graham and McCarthy 2006a; Arthur et al. 2017), the latter being especially important when fire treatments are combined with canopy reductions. Fine fuel loads can impact the heterogeneity of fire temperature and fuel consumption (Graham and McCarthy 2006b) and, thus, the availability of protected safe sites for acorns.

To better understand how prescribed fire affects germination and early seedling establishment of recently fallen acorns, we conducted plot-level $\left(1 \mathrm{~m}^{2}\right)$ burns in an upland oak stand in northern Mississippi during December 2018, using increasing fine fuel loads (single [i.e., ambient], double, and triple). These fuel loads represented those in nearby unburned (50+ years since fire) and recently firetreated (two years since fire) closed-canopy stands and were similar to those evaluated previously in burned and thinned mixed hardwood stands in Ohio, USA (Graham and McCarthy 2006a), and repeatedly burned oak stands in Kentucky, USA (Arthur et al. 2017). In a greenhouse, we tracked acorn germination, growth, and biomass allocation of seedlings originating from burned and unburned acorns of Shumard oak (Quercus shumardii Buckley) and white oak (Q. alba L.). These two species occurred in upland stands across the study area with substantial acorn production during 2018. Further, Q. alba, a white oak (section Quercus), and Q. shumardii, a red oak (section Lobatae), have different germination strategies. According to Greenberg and Parresol (2002), acorns of species in the white oak group exhibit non-dormancy and germinate soon after seedfall, while acorns of species in the red oak group remain dormant until spring. Thus, acorn vulnerability to fire damage may vary by species depending on burn season. We hypothesized that acorn germination rates, growth of newly established seedlings originating from burned acorns, and total seedling biomass would decline with increasing fine fuel loads due to more intense fires that were more likely to damage acorns. We expected acorns of white oak to be more susceptible to damage than those of Shumard oak because of their fall germination.

\section{Methods}

\section{Acorn collection}

We collected 6000 acorns of both Shumard oak and white oak under a mature tree of each species in Starkville, Mississippi, USA, on 13 November 2018, using an acorn picker (12"/30 cm Classic Flip-Up Small Acorn Picker; Bag-A-Nut, Jacksonville, Florida, USA). We visually inspected acorns for viability (Morina et al. 2017). Acorns with signs of acorn weevil (Coleoptera Linnaeus, 1758: Curculionidae Latreille, 1802) damage were discarded, and 
white oak acorns that were already germinating were not used. To determine the average size of acorns to use in the experiment, we measured the diameter of 100 acorns of each species. We found that $77 \%$ of Shumard oak acorns were between 1.70 and $1.95 \mathrm{~cm}$ in diameter, and $92 \%$ of white oak acorns were between 1.50 and $1.90 \mathrm{~cm}$ in diameter. We randomly selected a total of 630 acorns of each species with diameters within these ranges and stored them at $4.2^{\circ} \mathrm{C}$ until the experimental burn.

\section{Experimental burn \\ Study area}

We subjected collected acorns to experimental burns in a closed-canopy (98\% canopy cover) upland oak stand at Spirit Hill Farm, $\sim 25 \mathrm{~km}$ southwest of Holly Springs, Mississippi, USA, on 6 December 2018. Dominant overstory (>20 cm diameter at breast height; $\mathrm{DBH})$ species in the stand were mostly deciduous species and included southern red oak (Quercus falcata Michx.), white oak, post oak (Q. stellata Wangenh.), mockernut hickory (Carya tomentosa [Lam.] Nutt.), and sweetgum (Liquidambar styraciflua L.). Shumard oaks were present in the overstory but not dominant. Total overstory basal area was $24.3 \mathrm{~m}^{2} \mathrm{ha}^{-1}$. Mid-story (10 to $20 \mathrm{~cm} \mathrm{DBH)} \mathrm{basal}$ area totaled $1.95 \mathrm{~m}^{2} \mathrm{ha}^{-1}$, and common species included winged elm (Ulmus alata Michx.), hickory (Carya Nutt. spp.), and white ash (Fraxinus americana L.). Soils were from the Ruston-Providence complex, which includes well-drained sandy and silt loams (Soil Survey Staff 2020). The stand had not experienced any fire or timber harvesting for at least 50 years (B. Bowen, landowner of Spirit Hill Farm, Holly Springs, Mississippi, USA,

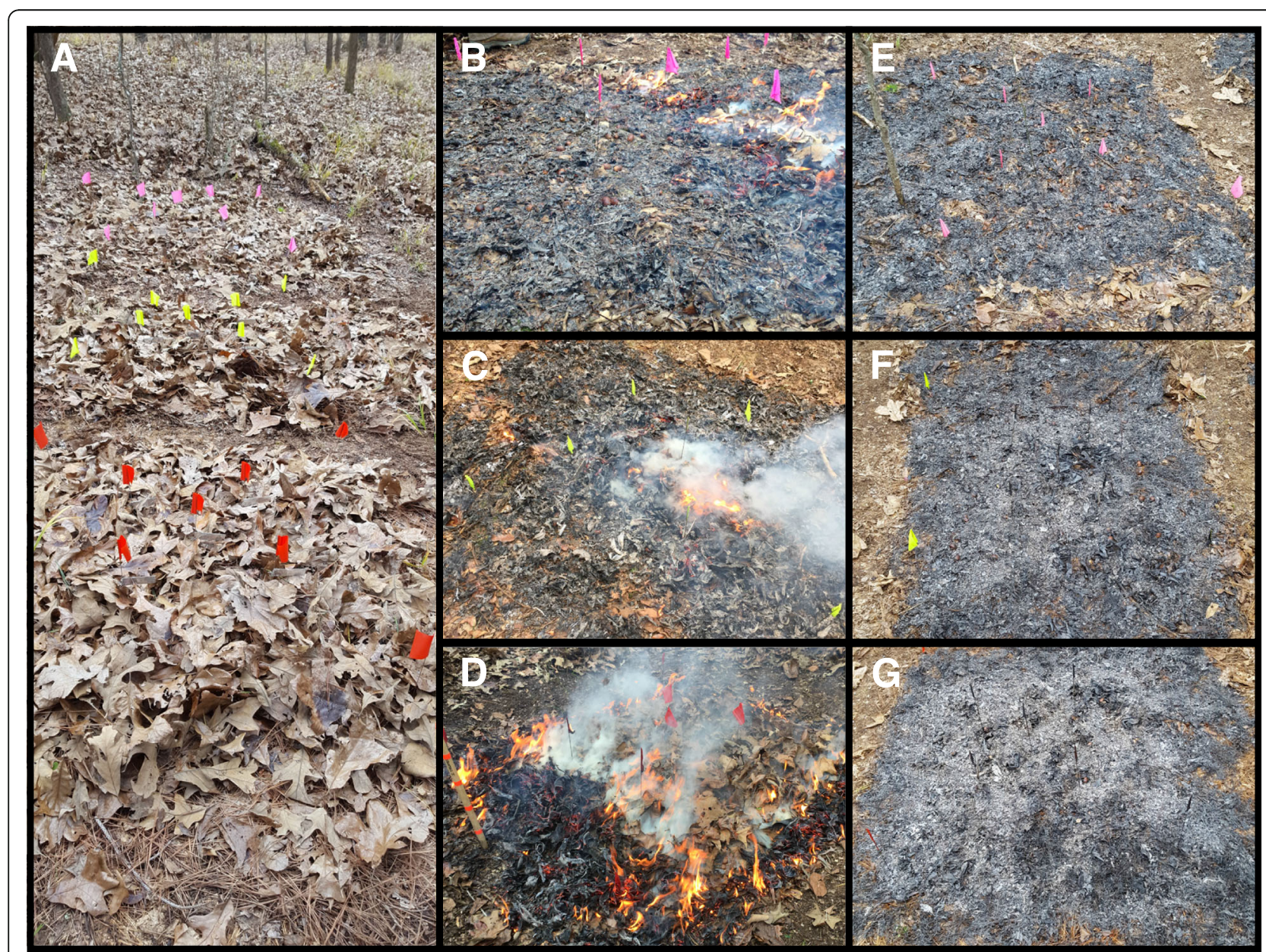

Fig. 1 (A) Single (pink flags, top), double (yellow flags, middle), and triple (red flags, bottom) fine fuel load treatment plots at Spirit Hill Farm, Mississippi, USA, immediately prior to burning in December 2018, which were used to test for fuel load treatment effects on white oak and Shumard oak acorns. (B) Single fine fuel load treatment plot during burning; (C) double fine fuel load treatment plot during burning; and (D) triple fine fuel load treatment plot during burning. (E) Single fine fuel load treatment plot immediately after burning; (F) double fine fuel load treatment plot immediately after burning; and (G) triple fine fuel load treatment plot immediately after burning. In the single fuel load treatment, acorns are clearly visible both (B) during burning and (E) after burning, and fuel consumption was more heterogeneous. Photos taken by authors H. Alexander, J. McDaniel, R. Nation, and A. Paulson 
personal communication). The historical fire regime in the region was low- to mixed-severity fires (Nowacki and Abrams 2008) that likely occurred every 4 to $6 \mathrm{yr}$ (Frost 1998).

\section{Study design and fine fuel treatments}

Within each of five replicate blocks located $\sim 50 \mathrm{~m}$ apart along flat ridges or gently sloping edges of ridges, we constructed three $1 \mathrm{~m}^{2}$ plots with randomly assigned fine fuel treatments with the following mean $( \pm$ SE) fine fuel depths and loads: single (depth: $2.3 \pm 0.4 \mathrm{~cm}$; dry weight: $2.78 \pm$ $0.18 \mathrm{Mg} \mathrm{ha}^{-1}$ ), double (depth: $6.5 \pm 0.4 \mathrm{~cm}$; dry weight $5.56 \pm 0.36 \mathrm{Mg} \mathrm{ha}^{-1}$ ), or triple (depth: $10.4 \pm 0.6 \mathrm{~cm}$; dry weight: $8.34 \pm 0.54 \mathrm{Mg} \mathrm{ha}^{-1}$ ) (Fig. 1a). The single fuel load treatment consisted of in situ leaf litter. The double fuel load treatments consisted of in situ litter in addition to litter collected from one undisturbed $1 \mathrm{~m}^{2}$ area adjacent to the burn plots, and triple fuel load treatments consisted of in situ litter in addition to litter collected from two undisturbed $1 \mathrm{~m}^{2}$ areas adjacent to the burn plots. Fine fuel added to the double and triple fuel load plots consisted of only leaf litter that had fallen that year and did not include partially decomposed litter or duff from previous years. Fine fuel mass of the single fuel treatment was determined by collecting leaf litter from a $1 \mathrm{~m}^{2}$ area adjacent to each block, drying at $60^{\circ} \mathrm{C}$ for $48 \mathrm{~h}$, and weighing. Fine fuel mass for the double and triple fuel load treatments were estimated by doubling or tripling the mass of the single fuel load treatment. Upland oak leaf litter, mostly post oak and southern red oak, dominated fine fuels (59 to 92\%) in all blocks. Fine fuel moisture varied between 17 and $37 \%$ (dry weight basis), exclusive of one sample with a moisture content of $63 \%$.
The fine fuel load treatments used in the experimental burns represented the range of fine fuel loads that naturally occurred within unburned (at least 50 years since fire) and recently burned (nine months to two years since fire), closed-canopy stands across Spirit Hill Farm (Table 1). We determined these fine fuel loads by collecting leaf litter within 12 to 20 quadrats $(30 \times 30 \mathrm{~cm})$ systematically placed throughout both unburned and burned areas on several sampling dates. Fine fuels were collected from unburned stands in March 2018 (four months after leaf fall) and January 2019 (one month after leaf fall), and from burned stands in March 2018 (immediately prior to burning; similar conditions as unburned stands), March 2018 (immediately post burn), January 2019 (nine months post burn; one month after leaf fall), and March 2020 (two years post burn; four months after leaf fall). After collection, these in situ fine fuels were oven dried $\left(60{ }^{\circ} \mathrm{C}\right)$ and weighed to calculate loads. Fuel loads from across the study area were then compared to those used in the experimental burn to determine what percentage of in situ fuel loads from different seasons and time since burn matched the fine fuel loads used in the experimental burn.

\section{Pre-burn setup}

Prior to burning, we removed woody debris from each plot to eliminate any confounding effects of woody fuels on fire behavior. Woody fuels were generally absent and, when found, mostly represented smaller sized (1- and 10-hour) fuels. We established a $0.2 \mathrm{~m}$ ignition zone around the perimeter of each burn plot consisting of ambient leaf litter so that we could ignite the fires outside the study plot, and then we raked a $0.5 \mathrm{~m}$ firebreak

Table 1 Sample size $(n)$, weight range (Min-Max; Mg ha $^{-1}$ ), and mean in situ fine fuel loads (Mean, Mg ha ${ }^{-1} ;$ ) within unburned (50+ years since fire) and recently burned (immediately, 9 mo, and 2 yr post burn) closed-canopy stands across the entire Spirit Hill Farm (SHF), Mississippi, USA, and the percent of these samples that fell within each fuel treatment range (Single, Double, Triple) used in the experimental burns conducted in December 2018 at a single stand at SHF to test for fuel load treatment effects on white oak and Shumard oak acorns (dry weight values: single $\leq 4.5 \mathrm{Mg} \mathrm{ha}^{-1}$; double $=4.5$ to $7.0 \mathrm{Mg} \mathrm{ha}{ }^{-1}$; triple $\geq 7.0 \mathrm{Mg} \mathrm{ha}^{-1}$ ). Fine fuel samples from across the study area were collected independently of those used in the experimental burns. Sample size for the March 2020 sampling date was only 12 because the burn unit area was smaller

\begin{tabular}{|c|c|c|c|c|c|c|}
\hline \multirow[b]{2}{*}{ Collection date } & \multirow[b]{2}{*}{$n$} & \multicolumn{2}{|c|}{$\begin{array}{l}\text { Dry weight of in situ fine fuel loads } \\
\left(\mathrm{Mg} \mathrm{ha}^{-1}\right)\end{array}$} & \multicolumn{3}{|c|}{$\begin{array}{l}\text { In situ samples in each fuel treatment } \\
\text { range (\%) }\end{array}$} \\
\hline & & Min-Max & Mean & Single & Double & Triple \\
\hline \multicolumn{7}{|l|}{ Unburned SHF } \\
\hline March 2018 (four months after leaf fall) & 20 & 1.28 to 9.10 & 4.05 & 68 & 29 & 3 \\
\hline January 2019 (one month after leaf fall) & 20 & 3.78 to 9.22 & 5.66 & 12 & 75 & 13 \\
\hline \multicolumn{7}{|l|}{ Burned SHF } \\
\hline March 2018 (immediately pre burn) & 20 & 2.11 to 7.24 & 4.29 & 55 & 44 & 2 \\
\hline March 2018 (immediately post burn) & 20 & $<0.01$ to 1.85 & 0.00 & 100 & 0 & c \\
\hline January 2019 (nine months post burn) & 20 & 2.57 to 11.07 & 6.05 & 13 & 74 & 13 \\
\hline March 2020 (two years post-burn) & 12 & 2.32 to 4.54 & 3.44 & 90 & 10 & c \\
\hline
\end{tabular}


beyond this ignition zone. We placed 30 acorns of each species in each plot just beneath the top of the leaf litter $(\sim 1 \mathrm{~cm})$ in a gridded fashion ( $20 \mathrm{~cm}$ apart). We chose this acorn density to approximate a "good" acorn production class (i.e., produced more acorns per $\mathrm{m}^{2}$ crown area than the five-year mean), as previously found for white oaks (Lashley et al. 2009). We were interested in fire effects on acorns in good crop years because mortality following pulsed masting events could be especially important for oak regeneration. Oaks exhibit high temporal variation in acorn production, both among and within species, with good crops every two to three years for red oaks and about once every five years for white oaks (Greenberg 2000; Rose et al. 2012). We placed acorns just beneath the leaf litter surface because we observed that many acorns were found at this depth soon after seedfall.

To assess relative differences in fire temperature near the leaf litter surface (i.e., acorn location) among fuel treatments, we placed five metal pyrometers $\sim 25 \mathrm{~cm}$ apart in each plot: one near plot center and four others in the center of each quadrant of the plot. Pyrometers were attached to pin flags and positioned vertically at the top of the litter layer. The distance from the bottom of the pyrometer to the bottom of the fuel bed was measured to estimate fuel depth. The pyrometers were constructed with aluminum tags painted with six Tempilaq fire-sensitive paints (Tempil, South Plainfield, New Jersey, USA) that melt and change color at specific temperatures $\left(79,163,246,316,399\right.$, and $510{ }^{\circ} \mathrm{C}$; Arthur et al. 2015). Although pyrometers only estimate the maximum temperature that the pyrometers themselves reach, rather than the actual temperature of the fire, their reliability for estimating mean maximum temperatures in comparison to thermocouples has been shown previously (Iverson et al. 2004). Most importantly, pyrometers are reliable for making relative comparisons among fire treatments within a study such as this when other methods are unavailable or prohibitively expensive (Wally et al. 2006).

\section{Burn implementation}

Immediately after acorn placement, we burned the plots with a ring fire, using a drip torch with a fuel mix of $60 \%$ diesel and $40 \%$ gasoline. The fire was ignited within the $0.2 \mathrm{~m}$ ignition zone outside of the plot but inside the fire break and allowed to spread beyond the drip torch fuel into litter before entering the plot (Fig. 1b through d). All burns were conducted mid-day between 1100 and 1300 hours when air temperature was 10 to $12^{\circ} \mathrm{C}$, relative humidity was 23 to $50 \%$, and winds were out of the southwest at 0.0 to $1 \mathrm{~m} \mathrm{~s}^{-1}$, as measured by a weather meter (Kestrel 5500 Fire Weather Pro; KestrelMeters. com, Boothwyn, Pennsylvania, USA). Two plots had to be fanned or relit to burn the entire plot due to slight rain at the time of those burns. One single fuel load plot failed to burn across the entire plot, so we created a duplicate plot adjacent to the original plot and used the duplicate plot for this study. Generally, fire rate of spread, measured as the time from when the fire entered the plot to the time when flames reached plot center, was slower in single $(123 \pm 44 \mathrm{~s})$ than in double $(95 \pm$ $23 \mathrm{~s})$ and triple fuel treatments $(53 \pm 17 \mathrm{~s})$. Maximum flame height, which was visually estimated every $30 \mathrm{~s}$ by comparing flame height to a stake marked at $5 \mathrm{~cm}$ intervals positioned opposite the recorder and $50 \mathrm{~cm}$ from the starting edge of the fire, was lower in single $(35 \pm 3 \mathrm{~cm})$ compared to double $(44 \pm 5 \mathrm{~cm})$ and triple fuel treatments $(57 \pm 3 \mathrm{~cm})$.

\section{Post fire}

Immediately post fire, we collected all acorns from each plot and stored the acorns at $4.2{ }^{\circ} \mathrm{C}$ until they were planted in the greenhouse the following week. Percent fuel consumption in each plot was estimated separately by two people by visually noting the percentage of the plot where fine fuels were consumed exposing bare mineral soil or duff, or leaving behind only ash (Fig. 1e, f). These two estimates were later averaged to produce a final estimate of percent fuel consumption. Pyrometers were removed, placed in individual plastic bags, and returned to the lab where mean maximum fire temperature was estimated as the mean of the highest temperature indicated by the five pyrometers in each plot. For four pyrometers that showed no melted paints, we used an ambient temperature of $10^{\circ} \mathrm{C}$.

\section{Acorn germination and oak seedling establishment}

On 10 December 2018, we planted the burned acorns and five replicates of 30 unburned acorns of each species in the Mississippi State University Environmental Plant Physiology Laboratory greenhouse. Within each 10Ellepot tray (Ellepot, Esbjerg, Denmark; https://www. ellepot.com/), acorns were planted $\sim 3.7 \mathrm{~cm}$ deep in their own individual circular Ellepot containing a standard sphagnum peat-based substrate. All 30 acorns (three trays) from each plot were placed together for ease of data collection. To account for any effects of potential varying environmental conditions within the greenhouse on seedling growth rates, the sets of 30 acorns were randomized across the greenhouse so that no two plots with the same treatment and species combination were adjacent to each other. Acorns were watered as needed (i.e., when the pots were visibly dry on the surface, typically one to two times per week) using either misting sprinklers or a sprayer head held at a position that mimicked rain falling gently from above (i.e., water sprayed upwards in an arc rather than from the side or directly 
down onto the seedlings). Temperature $\left(24.4 \pm 0.3{ }^{\circ} \mathrm{C}\right)$ and relative humidity $(47.5 \pm 1.4 \%)$ were monitored on a weekly basis using a weather meter (Kestrel 5500 Fire Weather Pro), and soil moisture (19.2 $\pm 1.8 \%$ volumetric water content) was monitored every two weeks using a soil moisture meter with $3 \mathrm{~cm}$ long probes (Field Scout TDR 100 Soil Moisture Meter, Item \#6440FS; Spectrum Technologies, Inc., Aurora, Illinois, USA). These measurements were recorded throughout the greenhouse to ensure relatively constant conditions for all Ellepot trays.

To standardize the measurement period between the two oak species with different germination strategies, we began recording acorn germination and seedling growth characteristics weekly once $\sim 50 \%$ of the unburned acorns for a given species had germinated, and continued measurements for 11 weeks, which was two weeks after the germination rates of the unburned acorns plateaued. Because of the delayed germination of Shumard oak acorns (Greenberg and Parresol 2002), the measurement period for Shumard oak seedlings began about four weeks after the white oaks. We classified acorns as germinated (defined as having cotyledons or radicle emerging from the acorn) or not germinated. For each acorn that germinated and produced a seedling, we measured seedling height $(\mathrm{cm})$ and basal diameter $(\mathrm{mm})$. Seedling height was measured with a ruler from the point where the stem emerged from the soil to the tip of the terminal bud, and basal diameter was measured with calipers perpendicular to the stem where it emerged from the soil.

\section{Seedling biomass}

To measure above- and belowground seedling biomass, we harvested approximately half of the living seedlings after the greenhouse experiment was complete and stored harvested seedlings at $4.2{ }^{\circ} \mathrm{C}$ until processing. We initially cleaned as much soil as possible from the roots of each harvested seedling using our hands for large amounts of soil and small paintbrushes for cleaning around the fine roots. Then we oven dried the seedlings at $60^{\circ} \mathrm{C}$ for about two days. We then gently removed any remaining soil from the roots using small paintbrushes and measured the oven-dried mass of the fine roots (i.e., smaller roots coming laterally off the taproot), taproot (i.e., main root extending downward off the stem), stem, and leaves.

\section{Data analysis}

We used a randomized complete block design to analyze differences in pyrometer-based estimates of mean maximum temperature and percent fuel consumption. We analyzed differences in percent acorn germination and seedling characteristics between species and fuel load treatments using a split-plot design with block as a random effect. Because so few acorns germinated from the double $(4.7 \%$ and $1.3 \%$ of Shumard oak and white oak acorns, respectively) and triple ( $0.7 \%$ and $0.0 \%$ of Shumard oak and white oak acorns, respectively) fuel load treatments, we analyzed germination rates and seedling characteristics from the single fuel load and unburned treatments only, and only included data from the final week of the greenhouse experiment (i.e., eleventh week of measurement, after $\sim 50 \%$ of unburned acorns of each species germinated). We confirmed that model residuals were normally distributed and showed no evidence of heterogeneity and used a square root or natural log transformation when necessary to improve the distribution of residuals. When appropriate, we used the emmeans package (Lenth 2019) to conduct Tukey's Honestly Significant Difference post-hoc tests (alpha $=0.05$; Tukey 1949) comparing estimated marginal means of individual fuel load treatments, species, or their interaction. All analyses were conducted in $\mathrm{R}$ version 3.6.0 ( $\mathrm{R}$ Core Team 2019), and split-plot analyses were conducted using the nlme package (Pinheiro et al. 2020).

\section{Results}

Higher fuel loads resulted in fires with higher mean maximum fire temperatures as detected with pyrometers, and greater percent fuel consumption. Mean maximum fire temperature was $\sim 60{ }^{\circ} \mathrm{C}$ higher in double $\left(386 \pm 13{ }^{\circ} \mathrm{C}\right)$ and triple $\left(387 \pm 30^{\circ} \mathrm{C}\right)$ fuel treatments than in the single $\left(323 \pm 36{ }^{\circ} \mathrm{C}\right)$ fuel treatment, but this difference was not significant $(F=1.5 ; \mathrm{df}=2,8 ; P=0.27)$. There was strong evidence for a difference in percent fuel consumption between different fuel treatments $(F=10.2 ; \mathrm{df}=2,8 ; P=$ $0.006)$. Percent fuel consumption was $\sim 30 \%$ higher in the double $(90 \pm 4 \%, P=0.019)$ and triple $(94 \pm 2 \%, P=$ $0.007)$ fuel treatments compared with the single $(70 \pm 8 \%)$ fuel treatment, and there was no difference between the double and triple fuel treatments $(P=0.77)$.

Burning negatively affected germination rates of both oak species (Fig. 2). The germination rate of unburned acorns was $87.7 \pm 2.3 \%$ compared to $40.7 \pm 4.8 \%$ in acorns burned with the single fuel treatment $(F=51.9$; $\mathrm{df}=1,8 ; P=0.0001)$. There was no evidence of an interaction between fuel load treatment and species $(F=$ $0.6 ; \mathrm{df}=1,8 ; P=0.46$ ) or of a difference in germination rates between Shumard oak and white oak acorns $(F=$ 2.7 ; $\mathrm{df}=1,8 ; P=0.10$ ). Less than $5 \%$ of acorns from either species germinated in the double and triple fuel treatments. Over $95 \%$ of acorns that germinated produced seedlings that survived the measurement period, so any seedling mortality was assumed to be unrelated to fuel treatments.

Seedling heights from acorns in the single fuel load treatment were approximately $11 \%(\sim 1.0 \mathrm{~cm})$ shorter than those from the unburned treatment (Fig. 3a; $F=$ 

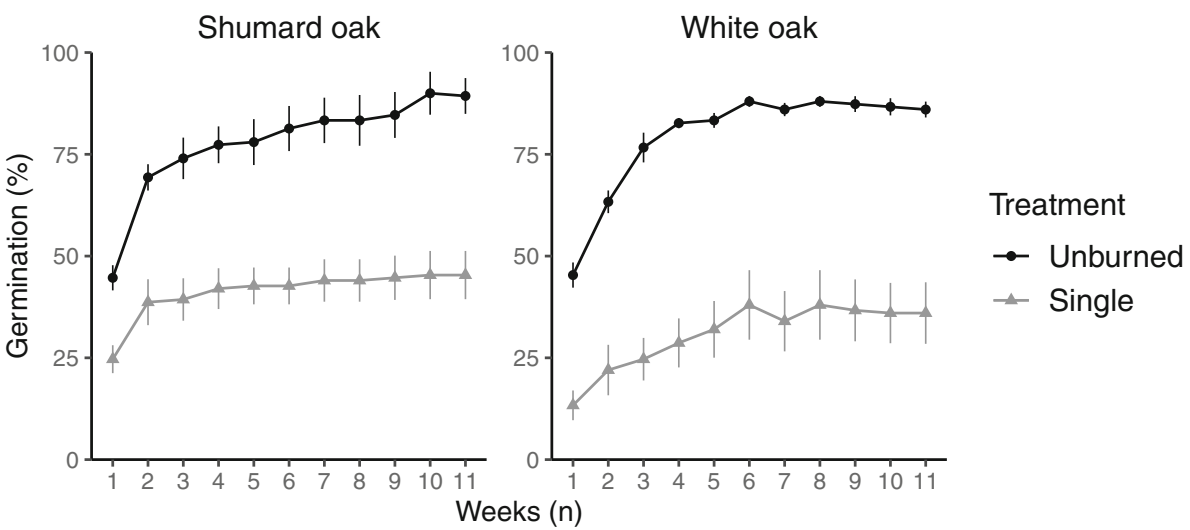

Fig. 2 Mean \pm standard error percent germination of Shumard oak and white oak acorns that were unburned compared to those experimentally burned at Spirit Hill Farm, Mississippi, USA, in December 2018, using single fuel load treatments. Acorns were germinated in greenhouse conditions and tracked over an 11-week period after unburned acorn germination rates reached $\sim 50 \%$
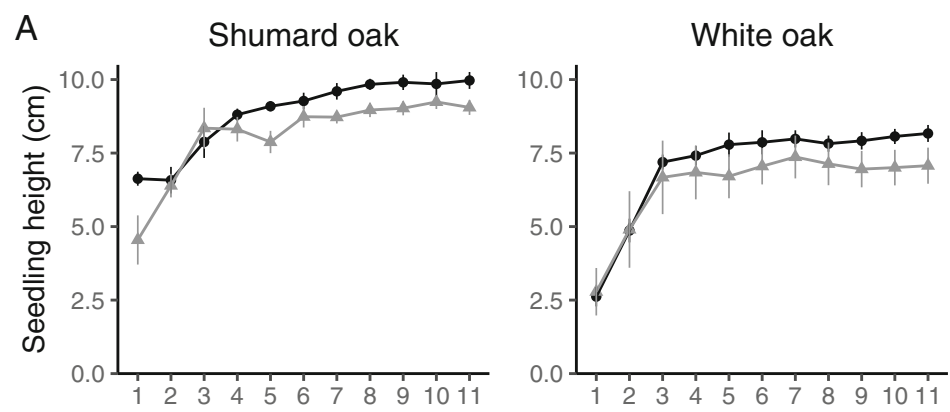

B
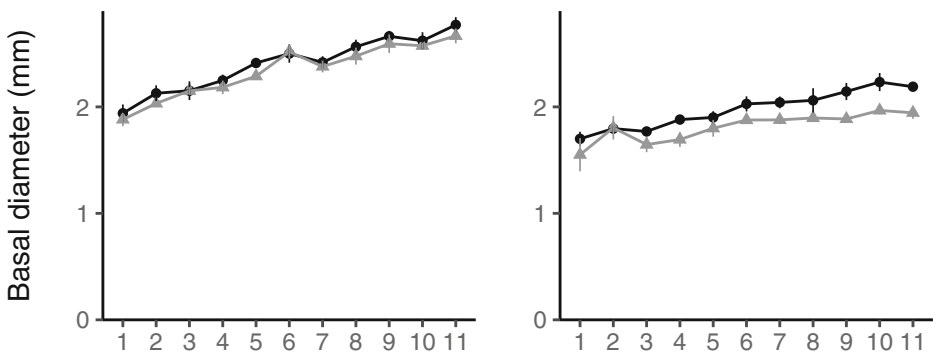

Treatment

$\rightarrow$ Unburned

- Single

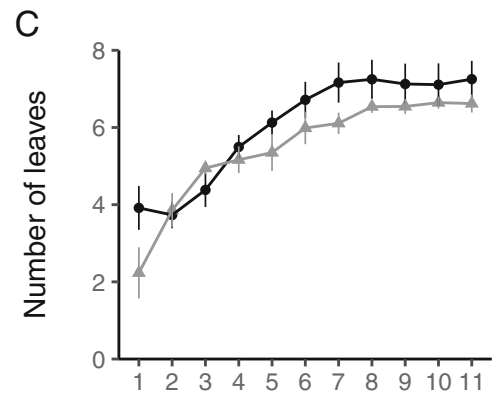

Weeks $(n)$

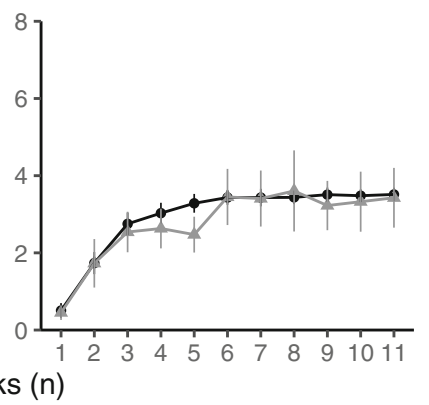

Fig. 3 Mean \pm standard error $(\mathbf{A})$ height $(\mathrm{cm})$, (B) basal diameter $(\mathrm{mm})$, and $(\mathbf{C})$ number of leaves of Shumard oak and white oak seedlings that germinated from acorns that were unburned compared to seedlings germinated from acorns that were experimentally burned using the single fuel load treatment at Spirit Hill Farm, Mississippi, USA, in December 2018. Acorns were germinated in greenhouse conditions and tracked over an 11-week period after unburned acorn germination rates reached $\sim 50 \%$ 
Table 2 Mean ( \pm standard error) biomass (dry weight; g) of Shumard oak and white oak seedlings grown from unburned acorns (Unburned), single fuel load treatment acorns (Single), and the mean biomass from both treatments (Mean). Although there was no difference in biomass between fuel load treatments, and no species and fuel load treatment interaction, we did identify differences in mean biomass between Shumard and white oaks, independent of fuel load treatment. Capital letter superscripts denote significant differences $(P<0.05)$ between species

\begin{tabular}{|c|c|c|c|c|c|c|}
\hline \multirow[b]{3}{*}{ Seedling component } & \multicolumn{6}{|c|}{ Seedling dry weight per species and fuel load treatment (g) } \\
\hline & \multicolumn{3}{|c|}{ Shumard oak } & \multicolumn{3}{|l|}{ White oak } \\
\hline & Unburned & Single & Mean & Unburned & Single & Mean \\
\hline Leaf & $0.74(0.04)$ & $0.71(0.05)$ & $0.73^{\mathrm{A}}(0.03)$ & $0.43(0.03)$ & $0.39(0.06)$ & $0.42^{\mathrm{A}}(0.03)$ \\
\hline Stem & $0.36(0.02)$ & $0.36(0.04)$ & $0.36^{A}(0.02)$ & $0.29(0.02)$ & $0.26(0.04)$ & $0.28^{\mathrm{B}}(0.02)$ \\
\hline Total aboveground & $1.10(0.06)$ & $1.08(0.06)$ & $1.09^{\mathrm{A}}(0.04)$ & $0.71(0.05)$ & $0.66(0.09)$ & $0.70^{B}(0.04)$ \\
\hline Fine root & $0.10(0.01)$ & $0.09(0.01)$ & $0.10^{\mathrm{A}}(0.01)$ & $0.08(0.01)$ & $0.08(0.01)$ & $0.08^{B}(0.01)$ \\
\hline Taproot & $0.65(0.04)$ & $0.64(0.04)$ & $0.65^{\mathrm{A}}(0.03)$ & $1.22(0.07)$ & $1.00(0.11)$ & $1.15^{B}(0.06)$ \\
\hline Total belowground & $0.75(0.05)$ & $0.74(0.04)$ & $0.75^{\mathrm{A}}(0.03)$ & $1.30(0.07)$ & $1.08(0.12)$ & $1.23^{B}(0.06)$ \\
\hline Root : shoot ratio & $0.70(0.03)$ & $0.73(0.03)$ & $0.71^{\mathrm{A}}(0.02)$ & $2.04(0.10)$ & $2.16(0.36)$ & $2.08^{\mathrm{B}}(0.13)$ \\
\hline
\end{tabular}

$5.7 ; \mathrm{df}=1,8 ; P=0.04)$, and Shumard oaks were approximately $24 \%$ taller $(1.9 \mathrm{~cm})$ than white oaks $(F=25.1$; $\mathrm{df}=1,371 ; P<0.0001)$. Basal diameters of Shumard oak seedlings were $28 \%(0.6 \mathrm{~mm})$ smaller than those of white oak seedlings (Fig. 3b; $F=98.0 ; \mathrm{df}=1,371 ; P<0.0001$ ), but there was no evidence of a burn effect on basal diameter $(F=3.4 ; \mathrm{df}=1,371 ; P=0.10)$. The number of leaves on seedlings from the single fuel load and unburned treatments were similar (Fig. 3c; $F=1.0, \mathrm{df}=1,8 ; P=0.35$ ), although white oak seedlings had $52 \%$ ( 3.6 leaves) fewer leaves than Shumard oak seedlings $(F=174.6$; $\mathrm{df}=1,371$; $P<0.0001)$. We did not find evidence of an interaction between fuel load treatment and species for seedling heights, basal diameter, or the number of leaves $(P>0.50$ in all cases). Biomass allocation patterns of seedlings originating from acorns exposed to single fuel load and unburned treatments were similar (Table 2; $P>0.10$ in all cases), with no evidence of an interaction for any of the biomass measurements $(P>0.05$ in all cases). In contrast, we did find species-level differences in biomass allocation patterns, for which white oak seedlings had 36\% less aboveground biomass (Table 2; $F=37.2$, $\mathrm{df}=1$, $168 ; P<0.0001$ ) and $65 \%$ more belowground biomass than Shumard oak seedlings $(F=52.2$, df $=1$, 168; $P<0.0001)$.

\section{Discussion}

Our results demonstrate that Shumard oak and white oak acorns located just beneath the leaf litter surface in upland oak forests are more likely to survive burns conducted just after leaf fall if fine fuel loads are in the lower range of those occurring in our study area. Our single fine fuel load treatment killed 49 to $58 \%$ of acorns, a finding comparable to mortality (40 to $49 \%$ ) of recently fallen northern red oak (Quercus rubra L.) acorns following a cool fall burn in northwestern Pennsylvania, USA
(Auchmoody and Clay Smith 1993). In contrast, double and triple fuel load treatments were overwhelmingly lethal ( $>95 \%$ failed to germinate) to acorns of both species, a finding similar to the $100 \%$ mortality of southern red oak acorns in the litter layer following a simulated winter (i.e., February) prescribed fire in Arkansas, USA (Cain and Shelton 1998). That study used fuel loads (dry weight $=2.90 \mathrm{Mg} \mathrm{ha}^{-1}$ ) similar to our single fuel load treatment, but fuels consisted of both oak and pine (Pinus L. spp.) litter, rather than mainly oak litter. As such, litter type may also contribute to fire behavior and acorn vulnerability.

In contrast to our expectation, acorn mortality did not appear related to mean maximum temperature detected by pyrometers, but was instead related to the degree of fuel consumption. The upper litter layer across all fuel treatments burned at a mean maximum temperature of at least $320{ }^{\circ} \mathrm{C}$, considerably higher than the $260{ }^{\circ} \mathrm{C}$ pyrometer-detected temperature threshold that was previously found to kill acorns (Greenberg et al. 2012). The lack of a temperature effect could be because pyrometers often underestimate actual fire temperatures and are insufficient for detecting fire intensity (Kennard et al. 2005). Fire intensity could be important for assessing fire effects on individual acorns, but is difficult to detect without the use of more sophisticated, and increasingly available, methods like infrared cameras (e.g., O'Brien et al. 2016; Kreye et al. 2020). Regardless, differences in germination rates among fine fuel treatments were likely due to differences in fuel consumption, which was $>90 \%$ in plots treated with double and triple fuel loads, compared to only $70 \%$ in plots treated with single fuel loads. Increased fuel consumption in the double and triple fuel treatments may have been because we added litter to plots receiving these treatments, which may have increased aeration and reduced bulk density of the litter, 
leading to more oxygen to carry fire between fuel particles. With less fuel consumption in the single fuel treatment, some acorns likely escaped burning, or burned less severely. Based on observation, single fuel load burns were more heterogeneous, with patches of unburned fuels throughout the plot. Many of these patches contained visibly intact acorns (Fig. $1 \mathrm{~b}$ and e), which were likely undamaged or minimally damaged. In acorns, up to $50 \%$ of the cotyledons' reserves are not essential for acorn germination and early seedling survival; the reserves in the apex of the acorn are more essential for acorn viability than those at the base of the acorn (Yi and Liu 2014; Yi et al. 2015). Thus, even burned acorns could survive and germinate if they did not experience severe damage in the area of the cotyledon that is essential for germination and survival. These findings indicate that burn heterogeneity is likely important for creating protected safe sites for acorns in oak-dominated ecosystems, and that heterogeneity may be increased when fuel loads are low. This highlights the potential for repeated application of low-intensity surface fires or canopy reductions for creating seedbed conditions conducive to successful acorn germination.

Our findings also indicate that seasonal changes in fine fuel loads could be important for acorn vulnerability to fire. Based on fuel samples collected across the entire study area (Table 1), fine fuel loads similar to those in the single fuel treatment were most common during the late dormant season (i.e., March). Fine fuel loads representative of double and triple fuel treatments were most common soon after leaf fall, regardless of whether or not the stand had been burned once before. Burns conducted later in the dormant season could give leaf litter more time to decompose, thereby reducing fine fuel loads compared to those earlier in the dormant season. For example, in upland oak stands in Kentucky, oak species lost 15 to $25 \%$ of their litter mass during the first three months of decomposition, and non-oak species like red and sugar maple lost 35 to 45\% (Alexander and Arthur 2014; Babl et al. 2020). However, any seasonal impact on acorn survival because of reduced fine fuel loads could be offset by a number of other factors. For example, rainfall events soon after leaf drop in the fall could act to compact litter, essentially making litter behavior similar to older, more decomposed litter. Further, both white and red oak acorns will have sprouted by late spring and may be more easily damaged by fire because of exposed vegetative tissue. Additionally, given that up to $90 \%$ of acorns are consumed by insects or vertebrate predators in most years (Lorimer 1993; Haas and Heske 2005) and up to $80 \%$ of acorns during a mast year succumb to desiccation and fungal rot within unburned litter layers (Brose 2011), spring-burn effects on acorns may be less important for overall regeneration potential than predation and other issues because the acorns are likely unviable by this time anyway. Thus, any seasonal effects on fine fuel loads must be considered in combination with acorn physiology and likelihood of acorn mortality from other causes to determine fire effects on acorn survival.

There are several important caveats related to our findings on acorn germination rates. One caveat is that we placed acorns just below the leaf litter surface. Acorns located on top of or mixed into the litter horizon are likely to be more exposed to flames and direct heat than those buried in soil or at the soil-litter interface, leading to increased damage from fire (Cain and Shelton 1998; Greenberg et al. 2012; Greenler et al. 2020). Thus, our germination rates based on acorns near the leaf litter surface are likely lower than those that would be found if some of the acorns were located in deeper litter or mineral soil horizons when burned. Another caveat is that we selected only viable acorns with no weevil damage and no signs of germination for our experiment. Previous research has shown that weevil-infested acorns that are burned have 20\% lower germination rates than those burned without weevil infestation (Auchmoody and Clay Smith 1993). As such, germination rates may have been lower if acorns with signs of weevil damage were included in our study. In addition, even though many of the white oak acorns that we collected had already begun to germinate prior to our experiment, we specifically selected acorns that showed no visible evidence of germination (e.g., exposed radicle) for this experiment. If we had chosen a random assortment of acorns that included those with evidence of germination, the acorns may have been more susceptible to damage, and white oak acorn mortality might have been higher.

Another important consideration is that we germinated acorns in a greenhouse rather than on the forest floor. Although this approach provides information on potential germination rates of both unburned and burned acorns, it does not represent reality. If acorns were placed on the forest floor, they may have been more exposed to fluctuations in moisture and temperature (Iverson and Hutchinson 2002) and increased risk of desiccation potential, insect infestation, or disease (Brose 2011). Further, fire consumption of leaf litter can increase acorn visibility to seed predators, which could increase seed predation rates (García et al. 2002), although a recent study showed that post-fire decreases in vegetation and litter cover also increase predation risk perceived by acorn predators, leading seed predators to avoid exposed conditions even with increased acorn visibility (Greenler et al. 2019). The fate of burned acorns may have been very different if they were allowed to emerge and establish in the field because of the interacting effects of changes in seedbed conditions and exposure to predation. 
Although there were no differences in basal diameter or biomass allocation patterns for acorns that survived to produce seedlings in a greenhouse setting, there was a slight decrease $(\sim 1 \mathrm{~cm}$ reduction, or 9 to $13 \%)$ in total height for seedlings originating from burned compared to unburned acorns. In the greenhouse, we noticed increased susceptibility of burned acorns to mold growth compared to unburned acorns, indicating that there may have been initially undetectable damage from burning (e.g., small cracks in acorn seed coat) that could have decreased seedling vigor, resulting in a small decrease in height. Most upland oak species have a conservative growth strategy as an adaptation to dry and fire-prone environments and allocate resources first to belowground biomass, then to stem growth (Abrams 1992). As such, the growth consequences for fire-damaged, yet still viable, acorns may be first evident in above- rather than belowground growth. Regardless of cause, the reduction in height indicates the potential for legacy effects of burning on seedling growth, although the magnitude of this effect as seedlings obtain larger size classes remains unknown.

\section{Conclusions}

Reducing fuel loads and increasing fuel heterogeneity in upland oak ecosystems through mechanisms such as prescribed fire or canopy reductions may be needed to help protect acorns from fire damage. Survival of Shumard oak and white oak acorns was greatest when burned with fine fuel loads representative of the lower range of fuel loads that occurred both within our study area (Table 1) and in burned or thinned mixed hardwood and oak stands in Ohio (Graham and McCarthy 2006a) and Kentucky (Arthur et al. 2017). When experimentally burned, the lowest fine fuel treatment created patchier burns with lower percent fuel consumption, likely providing safe sites for acorns. Acorns placed in fuel loads representative of the higher range of fuel loads found in these systems exhibited almost complete mortality post fire. Growth patterns in burned acorns that did germinate were similar to unburned acorns in all measured characteristics except height, which was reduced 9 to $13 \%$ in burned acorns of both species, indicating the potential for some legacy effects of fire damage on seedling growth.

These findings highlight the need for regular, repeated prescribed fires or canopy reductions to reduce fine fuel loads and improve fuel heterogeneity in historically pyrophytic, oak-dominated ecosystems. These strategies will not only reduce competition from encroaching competitor species but will also reduce damage to acorns in the leaf litter layer during fire. The positive effects on acorn germination rates, and ultimately on oak seedling establishment, however, will likely require repeated application of these treatments over a number of years to limit fuel re-accumulation, decrease canopy cover and associated fuel moisture (Kreye et al. 2020), and shift stand composition toward oak and other pyrophytic species with more flammable litter (Babl et al. 2020).

\section{Acknowledgements \\ We are grateful to B. and S. Bowen at Spirit Hill Farm for providing access to the experimental burn site. Thank you to M. Boggess for collecting the acorns used in the experiment, to J. Bankston and C. Goldsmith for assisting with fieldwork, to R. Arney for providing feedback on the experiment, to S. Woodward for collecting much of the fine fuel data across Spirit Hill Farm, and to S. Avery for processing fuel type samples from the experimental plots. Ellepot trays were donated by Knox Horticulture (Winter Garden, Florida, USA) and The Blackmore Company (Belleville, Michigan, USA). We thank the anonymous reviewers for their very insightful and helpful comments, which greatly improved this manuscript.}

\section{Authors' contributions}

$\mathrm{RN}, \mathrm{HA}, \mathrm{JM}$, and AP designed and carried out the experiment. GD contributed to the greenhouse experimental design and provided greenhouse assistance, materials, and monitoring. RN and AP conducted the statistical analyses and developed figures for the manuscript. RN wrote the initial draft of the manuscript, and HA, JM, and AP edited and revised the manuscript to produce the final version. All authors read and approved the final manuscript.

\section{Funding}

This study was funded in part by the National Institution of Food and Agriculture, US Department of Agriculture (NIFA-USDA) McIntire Stennis Capacity Grant awarded to H. Alexander (\#MISZ-069450), the Mississippi State University (MSU) Office of Research and Economic Development Undergraduate Research Program, and the MSU College of Forest Resources Undergraduate Research Scholars Program. This work is a contribution of the MSU Forest and Wildlife Research Center, the Mississippi Agricultural and Forestry Experiment Station, and Environmental Plant Physiology Laboratory. Any opinions, findings, conclusions, or recommendations expressed in this publication are those of the authors and do not necessarily reflect the view of the US Department of Agriculture.

\section{Availability of data and materials}

The datasets used or analyzed during this study are available from the corresponding author on reasonable request.

Ethics approval and consent to participate

Not applicable.

Consent for publication

Not applicable.

\section{Competing interests}

The authors declare that they have no competing interests.

\section{Author details}

${ }^{1}$ Department of Forestry, Forest and Wildlife Research Center, Mississippi State University, 775 Stone Boulevard, Starkville, Mississippi 39762, USA. ${ }^{2}$ School of Forestry and Wildlife Sciences, Auburn University, 602 Duncan Drive, Auburn, Alabama 36849-5418, USA. ${ }^{3}$ Department of Plant and Soil Sciences, Mississippi State University, 117 Dorman Hall, Starkville, Mississippi 39762, USA. ${ }^{4}$ Warnell School of Forestry and Natural Resources, University of Georgia, 180 East Green Street, Athens, Georgia 30605, USA.

Received: 14 May 2020 Accepted: 1 December 2020

Published online: 14 January 2021

\section{References}

Abrams, Marc D. 1992. Fire and the development of oak forests. BioScience 42: 346-353 https://doi.org/10.2307/1311781. 
Abrams, Marc D., and Gregory J. Nowacki. 2008. Native Americans as active and passive promoters of mast and fruit trees in the eastern USA. The Holocene 18: 1123-1137 https://doi.org/10.1177/0959683608095581.

Alexander, Heather D., and Mary A. Arthur. 2010. Implications of a predicted shift from upland oaks to red maple on forest hydrology and nutrient availability. Canadian Journal of Forest Research 40: 716-726 https://doi.org/10.1139/X10-029.

Alexander, Heather D., and Mary A. Arthur. 2014. Increasing red maple leaf litter alters decomposition rates and nitrogen cycling in historically oak-dominated forests of the eastern US. Ecosystems 17: 1371-1383 https://doi.org/10.1007/ s10021-014-9802-4.

Alexander, Heather D., Mary A. Arthur, David L. Loftis, and Stephanie R. Green. 2008. Survival and growth of upland oak and co-occurring competitor seedlings following single and repeated prescribed fires. Forest Ecology and Management 256: 1021-1030 https://doi.org/10.1016/j.foreco.2008.06.004.

Arthur, Mary A., Heather D. Alexander, Daniel C. Dey, Callie J. Schweitzer, and David L. Loftis. 2012. Refining the oak-fire hypothesis for management of oak-dominated forests of the eastern United States. Journal of Forestry 110: 257-266 https://doi.org/10.5849/jof.11-080.

Arthur, Mary A., Beth A. Blankenship, Angela Schörgendorfer, and Heather D. Alexander. 2017. Alterations to the fuel bed after single and repeated prescribed fires in an Appalachian hardwood forest. Forest Ecology and Management 403: 126-136 https://doi.org/10.1016/j.foreco.2017.08.011.

Arthur, Mary A., Beth A. Blankenship, Angela Schörgendorfer, David L. Loftis, and Heather D. Alexander. 2015. Changes in stand structure and tree vigor with repeated prescribed fire in an Appalachian hardwood forest. Forest Ecology and Management 340: 46-61 https://doi.org/10.1016/j.foreco.2014.12.025.

Auchmoody, L. R., and H. Clay Smith. 1993. Survival of northern red oak acorns after fall burning. Vol. Res. Pap. NE-678. Radnor, PA: US Department of Agriculture, Forest Service, Northeastern Forest Experiment. https://doi.org/ 10.2737/NE-RP-678

Babl, Emily K., Heather D. Alexander, Courtney M. Siegert, and John W. Willis. 2020. Could canopy, bark, and leaf litter traits of encroaching non-oak species influence future flammability of upland oak forests? Forest Ecology and Management 458: 1-11 https://doi.org/10.1016/j.foreco.2019. 117731.

Bova, Anthony S., and Matthew B. Dickinson. 2005. Linking surface-fire behavior, stem heating, and tissue necrosis. Canadian Journal of Forest Research 35: 814-822 https://doi.org/10.1139/x05-004.

Brose, Patrick. 2011. Fate of the 2001 acorn crop at Clear Creek State Forest, Pennsylvania. In In: Fei, Songlin; Lhotka, John M.; Stringer, Jeffrey W: Gottschalk, Kurt W.; Miller, Gary W., eds. Proceedings, 17th central hardwood forest conference; 2010 ; Lexington, KY; Gen. Tech. Rep. NRS-P-78. Newtown Square, PA: US Department of Agriculture, Forest Service, Northern Research Station: 253-261., 78:253-261.

Brose, Patrick, Daniel C. Dey, Thomas A. Waldrop, and others. 2014. The fire-oak literature of eastern North America: synthesis and guidelines. Gen Tech Rep NRS-135. Northern Research Station. Newtown Square, PA. https://doi.org/10. 2737/NRS-GTR-135

Brose, Patrick H. 2004. Fitting fire into oak management. In Upland oak ecology symposium: History, current conditions, and sustainability, 263. USDA For. Serv., Gen. Tech. Rep. SRS-73. Asheville, NC: Southern Research Station.

Brose, Patrick H. 2014. Development of prescribed fire as a silvicultural tool for the upland oak forests of the eastern United States. Journal of Forestry 112: 525-533 https://doi.org/10.5849/jof.13-088.

Brose, Patrick H., Daniel C. Dey, Ross J. Phillips, and Thomas A. Waldrop. 2013. A meta-analysis of the fire-oak hypothesis: does prescribed burning promote oak reproduction in eastern North America? Forest Science 59: 322-334 https://doi.org/10.5849/forsci.12-039.

Cain, Michael D., and Michael G. Shelton. 1998. Viability of litter-stored Quercus falcata Michx. acorns after simulated prescribed winter burns. International Journal of Wildland Fire 8: 199-203 https://doi.org/10.1071/ WF9980199.

Chiang, Jyh-Min, Mary A. Arthur, and Beth A. Blankenship. 2005. The effect of prescribed fire on gap fraction in an oak forest understory on the Cumberland Plateau1, 2. The Journal of the Torrey Botanical Society 132: 432-442 https://doi.org/10.3159/1095-5674(2005)132[432:TEOPFO]2.0.CO;2.

Dey, Daniel C. 2014. Sustaining oak forests in eastern North America: Regeneration and recruitment, the pillars of sustainability. Forest Science 60: 926-942 https://doi.org/10.5849/forsci.13-114.

Dillaway, Dylan N., Jeffrey W. Stringer, and Lynne K. Rieske. 2007. Light availability influences root carbohydrates, and potentially vigor, in white oak advance regeneration. Forest Ecology and Management 250: 227-233 https://doi.org/ 10.1016/j.foreco.2007.05.019.

Dyer, James M., and Todd F. Hutchinson. 2019. Topography and soils-based mapping reveals fine-scale compositional shifts over two centuries within a central Appalachian landscape. Forest Ecology and Management 433: 33-42 https://doi.org/10.1016/j.foreco.2018.10.052.

Fei, Songlin, Ningning Kong, Kim C. Steiner, W. Keith Moser, and Erik B. Steiner. 2011. Change in oak abundance in the eastern United States from 1980 to 2008. Forest Ecology and Management 262: 1370-1377 https://doi.org/10. 1016/j.foreco.2011.06.030.

Fei, Songlin, and Kim C. Steiner. 2007. Evidence for increasing red maple abundance in the eastern United States. Forest Science 53: 473-477.

Frost, Cecil C. 1998. Presettlement fire frequency regimes of the United States: a first approximation. In Fire in ecosystem management: shifting the paradigm from suppression to prescription. Tall Timbers Fire Ecology Conference Proceedings, vol. 20, 70-81.

García, Daniel, María-José Bañuelos, and Gilles Houle. 2002. Differential effects of acorn burial and litter cover on Quercus rubra recruitment at the limit of its range in eastern North America. Canadian Journal of Botany 80: 1115-1120 https://doi.org/10.1139/b02-102.

Graham, John B., and Brian C. McCarthy. 2006a. Forest floor fuel dynamics in mixed-oak forests of south-eastern Ohio. International Journal of Wildland Fire 15: 479-488 https://doi.org/10.1071/WF05108.

Graham, John B., and Brian C. McCarthy. 2006b. Effects of fine fuel moisture and loading on small scale fire behavior in mixed-oak forests of southeastern Ohio. Fire Ecology 2: 100-114 https://doi.org/10.4996/fireecology.0201100.

Greenberg, Cathryn H. 2000. Individual variation in acorn production by five species of southern Appalachian oaks. Forest Ecology and Management 132: 199-210 https://doi.org/10.1016/S0378-1127(99)00226-1.

Greenberg, Cathryn H., Tara L. Keyser, Stanley J. Zarnoch, Kristina Connor, Dean M. Simon, and Gordon S. Warburton. 2012. Acorn viability following prescribed fire in upland hardwood forests. Forest Ecology and Management 275: 79-86 https://doi.org/10.1016/j.foreco.2012.03.012.

Greenberg, Cathryn H., and Bernard R. Parresol. 2002. Dynamics of acorn production by five species of southern Appalachian oaks. In Oak forest ecosystems: ecology and management for wildlife, ed. William J. McShea and William M. Healy, 149-172. Baltimore: Johns Hopkins University Press.

Greenberg, Cathryn H., and Stan J. Zarnoch. 2018. A test of the predator satiation hypothesis, acorn predator size, and acorn preference. Canadian Journal of Forest Research 48: 237-245 https://doi.org/10.1139/cjfr-2017-0381.

Greenler, Skye M., Laura A. Estrada, Kenneth F. Kellner, Michael R. Saunders, and Robert K. Swihart. 2019. Prescribed fire and partial overstory removal alter an acorn-rodent conditional mutualism. Ecological Applications 29: e01958 https://doi.org/10.1002/eap.1958.

Greenler, Skye M., Robert K. Swihart, and Michael R. Saunders. 2020. Prescribed fire promotes acorn survival and seedling emergence from simulated caches. Forest Ecology and Management 464: 118063 https://doi.org/10.1016/j.foreco. 2020.118063.

Haas, Jared P., and Edward J. Heske. 2005. Experimental study of the effects of mammalian acorn predators on red oak acorn survival and germination. Journal of Mammalogy 86: 1015-1021 https://doi.org/10.1644/15451542(2005)86[1015:ESOTEO]2.0.CO;2.

Hammond, Darcy H., J. Morgan Varner, John S. Kush, and Zhaofei Fan. 2015. Contrasting sapling bark allocation of five southeastern USA hardwood tree species in a fire prone ecosystem. Ecosphere 6: 1-13 https://doi.org/10.1890/ ES15-00065.1.

Hanberry, Brice B., Heather D. Alexander, and Don Bragg. 2020. Open forest ecosystems: an excluded state. Forest Ecology and Management 472: 118256 https://doi.org/10.1016/j.foreco.2020.118256.

Hanberry, Brice B., Brian J. Palik, and S.He. Hong. 2012. Comparison of historical and current forest surveys for detection of homogenization and mesophication of Minnesota forests. Landscape Ecology 27: 1495-1512 https://doi.org/10.1007/s10980-012-9805-5.

Hutchinson, Todd F., Robert P. Long, Robert D. Ford, and Elaine Kennedy Sutherland. 2008. Fire history and the establishment of oaks and maples in second-growth forests. Canadian Journal of Forest Research 38: 1184-1198 https://doi.org/10.1139/X07-216.

Iverson, Louis R., and Todd F. Hutchinson. 2002. Soil temperature and moisture fluctuations during and after prescribed fire in mixed-oak forests, USA. Natural Areas Journal 22: 296-304. 
Iverson, Louis R., Daniel A. Yaussy, Joanne Rebbeck, Todd F. Hutchinson, Robert P. Long, and Anantha M. Prasad. 2004. A comparison of thermocouples and temperature paints to monitor spatial and temporal characteristics of landscape-scale prescribed fires. International Journal of Wildland Fire 13: 311322 https://doi.org/10.1071/WF03063.

Izbicki, Brian J., Heather D. Alexander, Alison K. Paulson, Brent R. Frey, Ryan W. McEwan, and Andrew I. Berry. 2020. Prescribed fire and natural canopy gap disturbances: Impacts on upland oak regeneration. Forest Ecology and Management 465: 118107 https://doi.org/10.1016/j.foreco.2020.118107.

Kennard, Deborah K., Kenneth W. Outcalt, David Jones, and Joseph J. O'Brien. 2005. Comparing techniques for estimating flame temperature of prescribed fires. Fire Ecology 1 (1): 75-84 https://doi.org/10.4996/fireecology.0101075.

Knapp, Eric E., Becky L. Estes, and Carl N. Skinner. 2009. Ecological effects of prescribed fire season: a literature review and synthesis for managers. General Technical Report PSW-GTR-224. Redding, CA: https://doi.org/10.2737/PSW-GTR-224.

Knott, Jonathan A., Johanna M. Desprez, Christopher M. Oswalt, and Songlin Fei. 2019. Shifts in forest composition in the eastern United States. Forest Ecology and Management 433: 176-183 https://doi.org/10.1016/j.foreco.2018.10.061.

Kreye, Jesse K., Jeffrey M. Kane, J. Morgan Varner, and J. Kevin Hiers. 2020. Radiant heating rapidly increases litter flammability through impacts on fuel moisture. Fire Ecology 16 (1): 1-10 https://doi.org/10.1186/s42408-020-0067-3.

Lashley, Marcus A., John M. McCord, Cathryn H. Greenberg, and Craig A. Harper. 2009. Masting characteristics of white oak: implications for management. In Proc. Annu. Conf. Southeast. Association Fish and Wildl. Agencies, vol. 63, 2126.

Lenth, R. 2019. emmeans: Estimated Marginal Means, aka Least-Squares Means. $R$ package version 1.3.4.

Lorimer, Craig G. 1993. Causes of the oak regeneration problem. In Oak regeneration: Serious problems, practical recommendations, 14-39. USDA For. Serv., Gen. Tech. Rep. SE-84. Asheville, NC: Southeastern Forest Experiment Station.

McEwan, Ryan W., James M. Dyer, and Neil Pederson. 2011. Multiple interacting ecosystem drivers: toward an encompassing hypothesis of oak forest dynamics across eastern North America. Ecography 34: 244-256 https://doi. org/10.1111/j.1600-0587.2010.06390.x.

McEwan, Ryan W., Todd F. Hutchinson, Robert P. Long, D. Robert Ford, and Brian C. McCarthy. 2007. Temporal and spatial patterns in fire occurrence during the establishment of mixed-oak forests in eastern North America. Journal of Vegetation Science 18: 655-664 https://doi.org/10.1111/j.1654-1103.2007. tb02579.x.

McShea, William J., William M. Healy, Patrick Devers, Todd Fearer, Frank H. Koch, Dean Stauffer, and Jeff Waldon. 2007. Forestry matters: decline of oaks will impact wildlife in hardwood forests. The Journal of Wildlife Management 71: 1717-1728 https://doi.org/10.2193/2006-169.

Morina, Daniel L., Marcus A. Lashley, M. Colter Chitwood, Christopher E. Moorman, and Christopher S. DePerno. 2017. Should we use the float test to quantify acorn viability? Wildlife Society Bulletin 41: 776-779 https://doi.org/ 10.1002/wsb.826.

Nowacki, Gregory J., and Marc D. Abrams. 2008. The demise of fire and "mesophication" of forests in the eastern United States. BioScience 58: 123$138 \mathrm{https}: / /$ doi.org/10.1641/B580207.

O'Brien, Joseph J., E. Louise Loudermilk, Benjamin Hornsby, Andrew T. Hudak, Benjamin C. Bright, Matthew B. Dickinson, J. Kevin Hiers, Casey Teske, and Roger D. Ottmar. 2016. High-resolution infrared thermography for capturing wildland fire behaviour: RxCADRE 2012. International Journal of Wildland Fire 25 (1): 62-75 https://doi.org/10.1071/WF14165.

Pinheiro, Jose, Douglas Bates, Saikat DebRoy, Deepayan Sarkar, and R. Core Team. 2020. nlme: Linear and Nonlinear Mixed Effects Models. R package version 3. 1-148. https://CRAN.R-project.org/package=nlme.

$\mathrm{R}$ Core Team. 2019. R: A language and environment for statistical coding. Austria: $R$ Foundation for Statistical Computing Vienna.

Rose, Anita K., Cathryn H. Greenberg, and Todd M. Fearer. 2012. Acorn production prediction models for five common oak species of the eastern United States. The Journal of Wildlife Management 76: 750-758 https://doi. org/10.1002/jwmg.291.

Siegert, Courtney M., Natasha A. Drotar, and Heather D. Alexander. 2019. Spatial and temporal variability of throughfall among oak and co-occurring non-oak tree species in an upland hardwood forest. Geosciences 9: 405 https://doi.org/ 10.3390/geosciences9100405.
Soil Survey Staff, Natural Resources Conservation Service, United States Department of Agriculture. Web Soil Survey. Available online at the following link: https://websoilsurvey.sc.egov.usda.gov/. Accessed [24 Mar 2020].

Tukey, J. 1949. Comparing Individual Means in the Analysis of Variance. Biometrics. 5 (2): 99-114 https://doi.org/10.2307/3001913.

Wally, Alaä L., Eric S. Menges, and Carl W. Weekley. 2006. Comparison of three devices for estimating fire temperatures in ecological studies. Applied Vegetation Science 9: 97-108 https://doi.org/10.1111/j.1654-109X.2006. tb00659.x.

Washburn, Carol S.M., and Mary A. Arthur. 2003. Spatial variability in soil nutrient availability in an oak-pine forest: potential effects of tree species. Canadian Journal of Forest Research 33: 2321-2330 https://doi.org/10.1139/x03-157.

Yi, Xianfeng, and Changqu Liu. 2014. Retention of cotyledons is crucial for resprouting of clipped oak seedlings. Scientific Reports 4: 1-5 https://doi.org/ 10.1038/srep05145

Yi, Xianfeng, Jinxin Zhang, and Zhenyu Wang. 2015. Large and small acorns contribute equally to early-stage oak seedlings: a multiple species study. European Journal of Forest Research 134: 1019-1026 https://doi.org/10.1007/ s10342-015-0906-y.

\section{Publisher's Note}

Springer Nature remains neutral with regard to jurisdictional claims in published maps and institutional affiliations.

\section{Submit your manuscript to a SpringerOpen ${ }^{\circ}$ journal and benefit from:}

- Convenient online submission

- Rigorous peer review

- Open access: articles freely available online

- High visibility within the field

- Retaining the copyright to your article

Submit your next manuscript at $\boldsymbol{\nabla}$ springeropen.com 